\title{
More coral, more fish? Contrasting snapshots from a remote Pacific atoll
}

Ricardo Beldade, Suzanne C Mills, Joachim Claudet, Isabelle M Côté

Coral reefs are in decline globally as a result of overexploitation, pollution, disease and, more recently, climate change. The impacts of changes in coral cover on associated fish communities can be difficult to predict because of the uneven dependence of reef fish species on corals for food, shelter or the three-dimensional structure they provide. We compared live coral cover, reef fish community metrics, and their associations, in two surveys of the lagoon of the remote atoll of Mataiva (French Polynesia) carried out 31 years apart. In contrast to the general pattern of decreasing coral cover reported for many parts of the Indo-Pacific region, live coral cover increased 6-7 fold at Mataiva between 1981 and 2012, and fish density nearly doubled. The stable overall reef fish species richness belied a significant shift in community structure. There was little overlap in community composition across years, and fish assemblages in 2012 were more homogeneous in composition than they were in 1981. Changes in species abundance were not clearly related to species-specific reliance on corals. The strong positive relationships between live coral cover and fish diversity and abundance noted in 1981, when coral cover rarely exceeded $10 \%$, were no longer present in 2012 , when coral cover rarely fell below this value. The most parsimonious explanation for these contrasting relationships is that, over the combined range of coral cover observed in the 1981 and 2012 snapshots, there is a rapidly asymptotic relationship between coral and fish. Our results, and other data from the south and west Pacific, suggest that fish diversity and abundance might accumulate rapidly up to a threshold of approximately $10 \%$ live coral cover. Such a relationship would have implications for our expectations of resistance and recovery of reef fish communities facing an increasingly severe regime of coral reef disturbances. 
${ }^{1}$ CRIOBE, USR 3278 CRIOBE CNRS-EPHE-UPVD, 66860 Perpignan Cedex, France

${ }^{2}$ Laboratoire d'Excellence "CORAIL"

${ }^{3}$ MARE - Marine and Environmental Sciences Centre, Faculdade de Ciências da Universidade de Lisboa, Campo Grande, 1749-016 Lisboa, Portugal

${ }^{4}$ Earth to Ocean Group, Department of Biological Sciences, Simon Fraser University, Burnaby, 


\section{INTRODUCTION}

14 Coral reefs are in decline globally as a result of overexploitation, pollution, disease and, more recently,

15 climate change (Hughes et al., 2003; Pandolfi et al., 2003; Bellwood et al., 2004; Eakin et al., 2010).

16 The patterns of loss in coral cover are well established for some reef-bearing regions, such as the

17 Caribbean (Gardner et al., 2003; Schutte et al., 2010) and the Great Barrier Reef (Ninio et al., 2000;

18 Sweatman et al., 2010). In contrast, for most parts of the Indo-Pacific region, which holds some three-

19 quarters of the world's coral reefs (Bruno \& Selig, 2007), the scale of coral loss was until recently

20 poorly documented. However, a large-scale, long-term quantitative analysis of coral data from this

21 region revealed an early onset of coral decline, generally low coral cover across all sub-regions, and

22 rates of coral loss of 1-2\% annually, even on some of the region's most intensively managed reefs

23 (Bruno \& Selig, 2007). This analysis also highlighted the paucity of long-term data from South Pacific

24 coral reefs, and in particular from the French Polynesian archipelagos (Bruno \& Selig, 2007; Chin et

25 al., 2011). The ongoing coral reef crisis threatens reef-building corals, more than one-third of which are

26 at an elevated risk of extinction (Carpenter et al., 2008), and the rich assemblages of other reef-

27 associated species (Bellwood et al., 2004; Pratchett et al., 2008).

The impact of the loss of coral cover on fish diversity and abundance should depend on the

29 extent to which fish rely on live coral (e.g., Graham et al., 2009). Declines in fish species number and

30 density have been observed after major disturbances, such as mass coral bleaching events and

31 population explosions of crown-of-thorns seastars (Acanthaster planci), which have led to extensive

32 coral mortality (e.g., Jones et al., 2004; Feary et al., 2007; Holbrook et al., 2008; Adjeroud et al., 2009;

33 Leray et al., 2012). However, knock-on effects on fish often manifest themselves after a considerable

34 time lag (10-15 years; Garpe et al., 2006; Graham et al., 2007; Alvarez-Filip et al., 2009), suggesting 
35 that coral structure may sometimes be as important as live coral cover for the maintenance of diversity 36 in reef fish assemblages (Garpe et al., 2006; Pratchett et al., 2008; Graham \& Nash, 2013). Moreover,

37 the repercussions of coral loss are usually uneven among taxa, with species that feed on coral (e.g.,

38 butterflyfishes) or depend on live coral for shelter (e.g., small damselfishes) showing more marked

39 declines than less dependent species (Garpe et al., 2006; Graham et al., 2006; Wilson et al., 2006;

40 Wilson et al., 2008; Emslie et al., 2011; Graham \& Nash, 2013). Some fish species may even benefit

41 from live coral reduction in the short term, when shifts in benthic composition lead to increased resource availability (Garpe et al., 2006; Graham et al., 2007).

The taxonomically variable reliance of reef fish on live coral suggests that the effect of changes in coral cover on reef fish diversity may be difficult to predict. Although a positive association between live coral cover and fish species richness and or abundance may be expected (e.g., Bell \& Galzin, 1984), it is not clear whether this relationship should be constant over all possible coral cover values. Arguably, as coral cover increases, the number of new coral-dependent species or individuals that can be added to existing fish communities should increase proportionately more slowly, leading to an asymptotic relationship between coral cover and fish community metrics (e.g., Holbrook et al., 2008). When coral cover is very high, fish diversity and/or abundance may even start to decline if coral reduces the availability of other microhabitat types (e.g., algal cover) upon which some species depend (Wilson et al., 2009; Glynn et al., 2014).

Our goal was to examine variability in the relationship between live coral cover and reef fish diversity and density to generate insights into the potential responses of fish communities to natural and anthropogenic disturbances on coral reefs. To do so, we replicated a survey of reef fish diversity undertaken 31 years ago by Bell \& Galzin (1984) in the lagoon of the Mataiva atoll, French Polynesia. Located far from large land masses, large human populations, and most local human impacts, the reefs 
58 of Mataiva, like those of most Polynesian islands, are considered to be under low anthropogenic threat

59 (Salvat et al., 2008; Wilkinson, 1998).

60

61

62

63

64

65

66

67

68

69

70

71

72

73

74

75

76

77

78

79

(1)

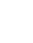

\section{MATERIALS AND METHODS}

\section{Study area}

The study was carried out on the atoll of Mataiva, the western-most atoll in the Tuamotu Archipelago, French Polynesia (14 $\left.{ }^{\circ} 55^{\prime} \mathrm{S}, 148^{\circ} 36^{\prime} \mathrm{W}\right)$. This small atoll $(10 \mathrm{~km}$ x $5 \mathrm{~km})$ has an unusual morphology with a reticulated lagoon divided into approximately 70 pools (average depth: $8 \mathrm{~m}$ ), separated by a network of slightly submerged coral reef partitions (Delesalle, 1985) (Fig. 1). In February 2012, we reassessed coral cover and fish assemblages in the same 13 pools as those surveyed in 1981 by Bell \& Galzin (1984).

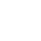

Bell \& Galzin (1984) estimated live coral cover along a single $50 \mathrm{~m}$ transect along the perimeter of each study pool, at depths of 0 to $3 \mathrm{~m}$. Their estimates of coral cover were qualitative, and they assigned each site to one of five coral cover categories: $0 \%$ (all dead), $<2 \%, 2-<5 \%, 5-10 \%$, and $>10 \%$. Bell \& Galzin (1984) reported that a subsequent quantitative evaluation of coral cover showed an average of $10.7 \%(\mathrm{SD}= \pm 9 \%)$ for sites in their $>10 \%$ category, providing support for their qualitative assessment.

In 2012, we estimated coral cover along three $50 \mathrm{~m}$ transects at each site surveyed by Bell \&

8 Galzin (1984). Transects were laid parallel to the rim of each pool at an average depth of $\approx 1.5 \mathrm{~m}$ (range: $0.5-3 \mathrm{~m}$ ), with as much distance as possible between transects. The total length of the reef 
80 rim around each pool varied, hence transects were separated by $5-30 \mathrm{~m}$. Using a point-intercept

81 method, we recorded benthic cover type every metre under the transect line (total: 51 points per

82 transect). Benthic cover categories included: live coral (to genus; mainly Acropora, Porites, Montipora

83 and various favid corals), macroalgae (mostly Turbinaria and Halimeda), other benthic organisms

84 (e.g., sponges), rubble, and sand (following Lison de Loma et al., 2008).

85 To check the accuracy of the point-intercept method, we also took a photograph of the

86 substratum at each intercept point (total: 51 photographs per transect) on 22 of the 39 transects. The

87 shallow depth of some parts of the transects prevented us from standardising the distance between

88 camera and reef, hence the size of the photoquadrats varied between $100 \mathrm{~cm}^{2}$ and $625 \mathrm{~cm}^{2}$. We placed

89 a digital grid on each photoquadrat and estimated percent live coral cover visually. We calculated

90 average coral cover for each transect by weighting the coral cover of each photograph by the area it

91 covered. The percent coral cover derived from the point-intercept method was significantly correlated

92 with the visual assessment of photoquadrats $(r=0.91, N=22$ transects, $P<0.0001)$. We therefore used

93 coral cover from the point-intercept survey in subsequent analyses.

94 two additional transects.

\section{Estimating fish diversity and density}

To estimate fish diversity and density, we faithfully replicated the method of Bell \& Galzin (1984). At each site, along one of the transects laid for coral assessment, we recorded the number of each species of reef fish within $2.5 \mathrm{~m}$ on either side of the transect line. Data were collected once by each of two observers at a 5 min interval. We did deviate from Bell \& Galzin (1984) by surveying fish on each of the other two transects laid for coral cover assessment. Each observer surveyed one of these 


\section{Data analysis}

\section{Changes in live coral cover}

The cover of each benthic category was expressed as the number of intercept points at which a category was present, divided by the total number of intercept points per transect. To obtain total coral cover comparable to Bell \& Galzin (1984), we summed the cover of all live coral genera within each transect. In analyses requiring all three transects surveyed, values were averaged across the transects at each site.

To assess changes in the percent coral cover, we conducted paired comparisons between live coral cover at each site in 1981 (from Bell \& Galzin, 1984) and in 2012 (this study). Because Bell \& Galzin (1984) reported coral cover in categories, we conservatively assigned the upper bound of each category to each site for 1981 . For their highest category $(>10 \%)$, we used a value of $20 \%$ coral cover, which is the mean coral cover $+1 \mathrm{SD}$ obtained in the subsequent quantitative coral survey. The results are similar if we assume that coral cover at the most coral-rich site in 1981 was as high as the highest cover we observed in 2012 (i.e., $45 \%$ ) so we elected to use only the lower (20\%), more conservative cover estimate. We performed one comparison between coral cover in 1981 and that obtained from a single transect (i.e., the transect surveyed by both fish observers) in 2012, which mirrors the sampling effort of Bell \& Galzin (1984), and one comparison using the average of the three 2012 transects. The results are similar, hence we present only the former below but show the additional results in the online supplement (Fig. S1a).

\section{Changes in reef fish community composition}

We compiled lists of reef fish species observed on the transects at each site in 1981 and 2012 to obtain estimates of fish species richness. We counted the numbers of species recorded in either and both surveys. 

significantly correlated at each of the 13 sites (mean correlation coefficient $r \pm \mathrm{SE}: 0.88 \pm 0.035$ ), and

129 the average slope of correlations across sites $(1.1 \pm 0.13)$ did not differ significantly from unity (one130 sample $t$-test, $t_{12}=0.76, P=0.46$ ). We thus averaged density estimates across the two observers at 131 each site, as did Bell \& Galzin (1984). We compared fish density (numbers per $250 \mathrm{~m}^{2}$ ) in 1981 and 132 2012, first using only the jointly surveyed 2012 transect to match the sampling effort of Bell \& Galzin 133 (1984), and then using the average of the three 2012 transects. Again, we present only the former here 134 but the additional results in the online supplement (Fig. S1b,c). To examine differences in fish assemblages between years, we ran a permutation-based, non136 parametric multivariate analysis of similarity (ANOSIM; Clarke, 1993) using PRIMER (v. 1.0.3;

137 Clarke \& Gorley, 2006). Abundance matrices (species by site) were compiled for 1981 and 2012, and 138 the data were square-root-transformed to reduce the influence of very abundant species. Bray-Curtis 139 similarity coefficients were computed between pairs of pools (Clarke \& Warwick, 2001). The ANOSIM procedure was carried out on the similarity matrix. ANOSIM generates an R statistic, which 141 varies between 0 (similarities within and between samples are the same) and 1 (all samples within 142 groups are more similar to each other than to any sample across groups) and is tested for difference 143 from zero with a permutation test (in this study, $\mathrm{N}=999$ permutations). We visualized the differences 144 in fish assemblages with a non-metric multidimensional scaling (MDS) plot in which samples that are 145 more similar in community composition appear closer together than more dissimilar samples. Stress 146 values of $<0.1$ suggest that distances among samples in an MDS plot accurately reflect the extent of 147 community differences (Clarke \& Warwick, 2001). We used the MVDisp procedure to estimate and 148 compare sample dispersion, i.e. variability in assemblages across pools in each year. Finally, we 149 conducted a similarity percentages (SIMPER) analysis to identify the main taxa responsible for the 150 differences observed between 1981 and 2012. We deemed taxa to be important to group differences if 
151 their individual dissimilarity contribution was $2.3 \%$ or more, which is twice the expected value if

152 dissimilarity were evenly partitioned among all taxa in the analysis (i.e., $100 \%$ divided by 87 taxa,

153 multiplied by two). The evenness of each taxon's dissimilarity contribution across sites was also

154 considered by examining the Consistency Ratio (CR), which is calculated by dividing a species'

155 average dissimilarity contribution by the standard deviation in dissimilarity values (of that species, for

156 the groups being compared). A CR value $>1$ indicates a taxon that contributed fairly equally across all 157 samples (Terlizzi et al., 2005).

158 To examine shifts in reef fish trophic structure, we assigned each positively identified species to 159 a specific trophic group (i.e., herbivore, coralivore, invertivore, piscivore or planktivore) based on the 160 main dietary items reported in Fishbase (Froese \& Pauly, 2014).

161

162

164

165

166

167

168

169

170

171

172

173

174

\section{Association between live coral cover and fish community}

We investigated variation in the relationships between live coral cover and fish species richness and density by fitting linear regressions between these two variables for 1981 and separately for 2012 . Combining the datasets would have violated the assumption of independence of data points since the same sites were sampled 31years apart. Other assumptions of parametric testing were met. We again assumed that coral cover in Bell and Galzin's highest coral category was $20 \%$.

Finally, we further examined the association between live coral and fish by comparing the magnitude of changes in density from 1981 to 2012 between fish species that rely heavily on live coral and those that do not. We categorised fish species as reliant on coral if (1) they use specific coral species as shelter or were described as exclusively associated with coral-rich areas, or (2) they commonly consume coral polyps, as stated on Fishbase (Froese \& Pauly, 2014; see Table S1). Coral reliance was not assessed for 10 taxa that were not identified to species.

Peer] reviewing PDF | (v2014:11:3123:4:0:NEW 6 Jan 2015) 


\section{RESULTS}

176

177

178

179

180

181

182

183

184

185

186

187

188

189

190

191

192

193

194

195

196

197

198

\section{Changes in live coral cover}

In 1981,4 of 13 sites (31\%) had no live coral, and maximum coral cover was over $10 \%$ at just one site. In 2012, all sites had some coral (Fig. 2a), and the two lowest coral cover categories used by Bell \& Galzin (1984) (i.e., 0\% and <2\%) were no longer represented. Mean coral cover in 1981 was approximately $4 \%( \pm 5.6 \% \mathrm{SD})$, assuming that coral cover was $20 \%$ at the most coral-rich site. Live coral cover was significantly higher in 2012 , with a mean of $28.7 \%( \pm 14.3 \%)$ (paired t-test, $t_{12}=6.3, P$ $<0.0001$; Fig. 2a). Mean coral cover derived from three transects at each site in 2012 was $24.4 \% \pm$ $10.9 \%$ (Fig. S1a). 
We recorded significantly more fish species per site in $2012\left(25.2 \pm 6.7\right.$ species $\left.250 \mathrm{~m}^{-2}\right)$ than in $1981\left(15.1 \pm 8.2\right.$ species $\left.250 \mathrm{~m}^{-2}\right)$ (paired $t$-test, $t_{12}=4.12, P=0.001 ;$ Fig. $\left.2 \mathrm{~b}\right)$. Fish density was also

201 higher in $2012\left(193.0 \pm 110.2\right.$ fish $250 \mathrm{~m}^{-2}$ vs $98.5 \pm 77.4$ fish $250 \mathrm{~m}^{-2}$ in 1981) (paired $t$-test, $t_{12}=3.1$, $202 P=0.009$; Fig. 2 c). The majority of species $(59 \%$, or 51 out of 87 ) increased in abundance between

203 the two surveys. In 1981, only six taxa (Cheilodipterus quinquelineatus, Chaetodon ephippium, 204 Chromis viridis, Scarus spp., Acanthurus triostegus and Amblyogobius phalaena) were present at 9 or 205 more of the sites (Table S1). In 2012, these six taxa remained widespread, but nine more species 206 (Chaetodon auriga, C. lunulatus, Abudefduf sexfasciatus, Dascyllus aruanus, Halichoeres trimaculatus, Thalassoma hardwicki, T. quinquevittata, Chlorurus sordidus and an unidentified goby) were found at most sites (Table S1).

In general, fish species density estimates in 1981 and 2012 were positively related $(r=0.38, N$ $210=87$ species, $P<0.0001$ ), but there were mismatches that were reflected in the community analysis.

211 The fish community composition was significantly different in 1981 and 2012 (ANOSIM, $R=0.40, P$ $212=0.001$ ). The MDS plot revealed little overlap in fish assemblages between 1981 and 2012 (Fig. 3), 213 and assemblages in 1981 were less similar to each other (within-group similarity = 37.3\%; dispersion 214 value $=1.24)$ than in $2012($ within-group similarity $=49.2 \%$; dispersion value $=0.76)$. Ten taxa in six 215 families contributed disproportionately to differences in community composition between 1981 and 2162012 (Table 1). Seven of these species were more abundant in 2012. Reef fish trophic composition shifted between the two surveys. While the proportion of 218 herbivores and invertivores remained constant (23\% and 46\%, respectively) across years, there was a 2192.5 -fold decline in the proportions of coralivores and piscivores (from $16 \%$ to $6 \%$ in both cases). 220 Planktivores were absent in 1981 but accounted for $18 \%$ of species in 2012 (Table S2). 
In 1981 there were significant, positive relationships between live coral cover and fish species

224 richness $\left(\mathrm{R}^{2}=0.83, \mathrm{~F}_{1,11}=51.7, \mathrm{p}<0.0001\right)$ as well as fish density $\left(\mathrm{R}^{2}=0.65, \mathrm{~F}_{1,11}=20.2, \mathrm{p}=0.001\right)$.

225 These relationships were no longer found in 2012 (fish species richness: $\mathrm{R}^{2}=0, \mathrm{~F}_{1,11}=0.002, \mathrm{p}=0.97$;

226 density: $\mathrm{R}^{2}=0, \mathrm{~F}_{1,11}=0.003, \mathrm{p}=0.96$ ) (Fig. 4).

Nearly three-quarters $(73 \%)$ of species that rely on live coral for shelter or food increased in

228 density between 1981 and 2012, compared to 57\% of species that are not coral-reliant. This association

229 was not significant $\left(\mathrm{X}^{2}{ }_{1}=1.52, \mathrm{p}=0.22\right)$. In addition, there was no difference in the magnitude of

230 density change from 1981 to 2012 between species that do and do not rely on live coral (change in

231 density of coral-reliant species: $+1.65 \pm 3.7$ fish per $250 \mathrm{~m}^{2}$; non-reliant species: $+1.05 \pm 5.7$ fish per

$\left.232250 \mathrm{~m}^{2} ; \mathrm{t}_{75}=0.47, \mathrm{p}=0.64\right)$.

233

\section{DISCUSSION}

richness in the lagoon did not increase appreciably, there was a significant shift in fish community 
rapidly up to a threshold of approximately $10 \%$ live coral cover. Such a relationship would have implications for our expectations of resistance and recovery of coral reefs to major disturbances.

In contrast to the general patterns of decreasing coral cover reported for many parts of the IndoPacific region (e.g., Bruno \& Selig, 2007), there was a marked increase in coral cover at the majority of sites in the Mataiva lagoon. The exact trajectory of change and the reasons for this improvement in coral abundance are not clear. Anthropogenic impacts on Mataiva reefs are relatively limited because of the small human population $(<300$ people), the scarcity of pollution sources, and the low fishing pressure (personal observations). Coral reefs in the region have experienced multiple natural disturbances, but records for Mataiva - especially for the lagoon - are limited. Bell \& Galzin (1984) surmised that average coral cover was very low (4\%) in 1981 because of coral mortality caused by prolonged low tides in the lagoon six months prior to their survey. Thereafter, the atoll was affected by two successive cyclones in 1983, an algal bloom in 1988, and mass coral bleaching in 1998 (Adjeroud et al., 2005). The abrupt drop in coral cover at a site monitored irregularly on the outer slope of the atoll between 1994 (25\%) and 1999 (5\%) was attributed mainly to coral bleaching in 1998 (Adjeroud et al., 2005). Corals within the Mataiva lagoon may have also been affected by bleaching, similarly to corals in the Rangiroa lagoon, $80 \mathrm{~km}$ away, which experienced severe mortality during the same warming event (Mumby et al., 2001). Later cyclones and bleaching events that have not been reported might have also had impacts on Mataiva corals. The recovery of Mataiva corals, from 4 to $30 \%$ cover, is therefore likely to have been uneven over time, and has probably occurred over a shorter period (i.e, since the last unrecorded disturbance) than the 31-year span of our two snapshots. Such a potentially rapid, post-disturbance increase in coral cover is not unprecedented (e.g., Diaz-Pulido et al., 2009;

Gilmour et al., 2013; Roff et al., 2014), but we cannot determine whether recovery indicates resilience, i.e. a return to pre-disturbance community structure (Connell \& Sousa, 1983), because of the lack of early, species-specific coral cover data. 
Reef fish communities can show a range of responses to coral recovery. Some communities

270 fail to return to pre-disturbance levels of species diversity and abundance, even after long periods of

271 time (e.g., Bellwood et al., 2012). Others appear to be truly resilient and, eventually, have community

272 structures that are almost indistinguishable from the initial assemblages (e.g., Sano et al., 1987, 2000).

273 However, some reef fish communities show recovery of overall diversity and abundance without

274 community resilience (e.g., Halford et al., 2004; Berumen \& Pratchett, 2006). It is difficult to assign

275 Mataiva to one of these three patterns without knowing whether the 1981 fish communities represent

276 pre- or post-disturbance assemblages. However, we did find that fish density nearly doubled as coral

277 cover increased but the species composition of the later fish assemblage was significantly different

278 from that of 1981. While all species that were found at the majority of sites in 1981 were found again

279 at the same sites in 2012, several more species became widespread in 2012. Species densities were

280 correlated between the two years, but the relationship was weak, explaining only $14 \%$ of variance in

281 density. The majority (60\%) of fish species increased in abundance but $40 \%$ declined or their

282 abundance remained unchanged. Those that did not increase included species spanning 16 families and

283 a range of body sizes, trophic groups and reliance on coral (Table S1). Ultimately, there was limited

284 overlap in community composition across years, and fish assemblages in 2012 were more

285 homogeneous in composition across sites than they were in 1981 (see also Emslie et al., 2008). This

286 convergence would be expected if there is a non-linear relationship between fish and coral cover (see

287 below).

288 Interestingly, total fish species richness in the lagoon remained remarkably similar despite

289 marked increases in site-specific fish species richness and density over time. However, only half of the

290 fish species were reported in both years. The fact that species not recorded in one survey tended to

291 always occur at very low density in the other survey suggests an issue with the detection of rare

292 species, but there might also be real additions or losses of species. Thus, the relatively constant overall 
293 species richness over time might belie a temporal substitution of several of the least abundant species

294 (Cheal et al., 2008; Dornelas et al., 2014). Metrics such as total species number and coral cover that 295 mask community composition are therefore poor indicators of community resilience.

Changes in fish species density in Mataiva were not as strongly associated with the reliance of

297 species on live coral as initially expected. In general, fish that depend heavily on live coral for either

298 food (e.g., many butterflyfishes) or shelter (e.g., small damselfishes in branching Acropora) are

299 expected to track closely the abundance of live coral (Jones et al., 2004; Pratchett et al., 2008). Indeed,

300 nearly three-quarters of the species we identified as coral-dependent did become more abundant

301 between 1981 and 2012. It is likely, for example, that a greater availability of branching corals

302 explains the marked increase in relative importance to species richness of planktivores, many of which

303 are closely tied to this habitat type. Coral composition was not recorded in 1981, hence we cannot test

304 this idea. However, more than half of the fish species that do not rely on coral also increased in

305 density. The density of coral-dependent species did not increase more than that of other fish species.

306 Moreover, coral-dependent species at Mataiva did not contribute disproportionately to differences

307 between the 1981 and 2012 assemblages (i.e., 4 coral-dependent species out of 9 species in Table 1 vs

30826 out of 77 species overall), and coralivorous species accounted for a smaller proportion of the fish

309 richness in 2012 than in 1981. The recovery of corals must therefore have improved reef habitat in

310 other ways than by simply increasing the availability of live coral. One such way is through increased

311 topographic complexity, which tends to be higher in coral-rich areas and is a recognised determinant of

312 reef fish community structure (Garpe et al., 2006). Many of the fish species that became more abundant

313 in 2012 but were not strictly dependent on live coral per se might depend instead on some of the

314 diverse microhabitats and shelters provided by architecturally complex corals (e.g., Sano et al. 1984).

315 Others might have responded to changes in fish prey availability, driven by benthic habitat change

316 (e.g., Graham et al. 2007). 
The relationships between live coral cover and reef fish diversity and abundance were variable

318 over time. Fish richness and density were strongly and positively associated with live coral cover in

3191981 when coral cover was very low $(<\sim 10 \%)$. This was not the case in 2012, when coral cover

320 varied between 10 and $\sim 50 \%$. When combined, our two snapshots - taken 31 years apart - suggest a

321 rapidly asymptotic relationship between coral and fish (see also Holbrook et al., 2008; Wilson et al.,

322 2009). Interestingly, the threshold coral cover we infer from this hypothesised relationship for lagoonal

323 reefs at Mataiva $(\sim 10 \%)$ is very similar to that noted in a study using space-for-time substitution of

324 natural and experimental reefs in Moorea, French Polynesia (Holbrook et al., 2008) and another using

325 time-series of natural reefs on the Great Barrier Reef (Wilson et al., 2009). This threshold coral cover

326 may therefore be a general feature, at least for coral reefs of the south and west Pacific.

If the hypothesised non-linear relationship between coral and fish is indeed accurate, it has

implications for our expectations of resistance and recovery of fish communities on disturbed reefs. It

329 suggests that fish assemblages on most reefs should be able to weather heavy losses of live coral cover

330 without showing concomitantly large responses by fishes, at least in terms of overall diversity and

331 abundance, until live coral cover drops below approximately 10\%. Further declines in coral cover

332 should lead to precipitous losses in reef fish. Conversely, the recovery of these simple metrics of fish

333 communities should be swift as coral recovers to the threshold level, although true resilience in the

334 sense of returning to original community structure may take longer, if it occurs at all. A key question

335 to address now is whether the tipping point in coral cover we and others have identified for reef fish

336 communities is affected by the increasing severity and frequency of multiple disturbances on coral 337 reefs. 
340 Acknowledgements. We thank Riccardo Rodolfo-Metalpa and Luiza Paoliello for field and data 341 analysis assistance respectively, and the Pension Ariiheevai (especially Francois Tetuira) for their 342 wonderful hospitality and providing the facilities to conduct this study.

343

344

345

346

347

348

349

350

351

352

353

354

355

356

357

358

359

360

361

\section{LITERATURE CITED}

Adjeroud M, Chancerelle Y, Schrimm M, Perez T, Lecchini D, Galzin R, Salvat B. 2005. Detecting the effects of natural disturbances on coral assemblages in French Polynesia: A decade survey at multiple scales. Aquatic Living Resources 18:111-123.

Adjeroud M, Michonneau F, Edmunds PJ, Chancerelle Y, Loma TL, Penin L, Thibaut L, Vidal-Dupiol J, Salvat B, Galzin R. 2009. Recurrent disturbances, recovery trajectories, and resilience of coral assemblages on a South Central Pacific reef. Coral Reefs 28:775-780.

Alvarez-Filip L, Côté IM, Gill JA, Watkinson AR, Dulvy NK. 2011. Region-wide temporal and spatial variation in Caribbean reef architecture: is coral cover the whole story? Global Change Biology $17: 2470-2477$.

Bell JD, Galzin R. 1984. Influence of live coral cover on coral-reef fish communities. Marine Ecology Progress Series 15:265-274

Bellwood DR, Hughes TP, Folke C, Nyström M. 2004. Confronting the coral reef crisis. Nature 429:827-33

Bellwood DR, Baird AH, Depczynski M, González-Cabello A, Hoey AS, Lefèvre CD, Tanner JK. 2012. Coral recovery may not herald the return of fishes on damaged coral reefs. Oecologia $170: 567-73$ 
362 Berumen ML, Pratchett MS. 2006. Recovery without resilience: persistent disturbance and long-term shifts in the structure of fish and coral communities at Tiahura Reef, Moorea. Coral Reefs 25:647653

Bruno JF, Selig ER. 2007. Regional decline of coral cover in the Indo-Pacific: timing, extent, and subregional comparisons. PLoS One 2:e711

Carpenter KE, Abrar M, Aeby G, Aronson RB, Banks S, Bruckner A, Chiriboga A, Cortés J, Delbeek JC, Devantier L, Edgar GJ, Edwards AJ, Fenner D, Guzmán HM, Hoeksema BW, Hodgson G, Johan O, Licuanan WY, Livingstone SR, Lovell ER, Moore JA, Obura DO, Ochavillo D, Polidoro BA, Precht WF, Quibilan MC, Reboton C, Richards ZT, Rogers AD, Sanciangco J, Sheppard A, Sheppard C, Smith J, Stuart S, Turak E, Veron JEN, Wallace C, Weil E, Wood E. 2008. One-third of reef-building corals face elevated extinction risk from climate change and local impacts. Science 321:560-3

Cheal AJ, Wilson SK, Emslie MJ, Dolman AM, Sweatman H. 2008. Responses of reef fish communities to coral declines on the Great Barrier Reef. Marine Ecology Progress Series $372: 211-223$

Chin A, Lison de Loma T, Reytar K, Planes S, Gerhardt K, Clua E, Burke L, Wilkinson C. 2011. Status of Coral Reefs of the Pacific and Outlook: 2011. Publishers Global Coral Reef Monitoring Network

Clarke KR. 1993. Non-parametric multivariate analyses of changes in community structure. Australian Journal of Ecology 18:117-143

Clarke KR, Warwick RM (2001) Change in Marine Communities: An Approach to Statistical Analysis and Interpretation, 2nd ed. PRIMER-E, Plymouth, UK

Clarke KR, Gorley RN. 2006. PRIMER V6: User Manual/Tutorial. PRIMER-E, Plymouth, UK. 
385 Connell JH, Sousa WP. 1983. On the Evidence Needed to Judge Ecological Stability or Persistence. American Naturalist 121:789-824

387 Delesalle B. 1985. Mataiva Atoll, Tuamotu archipelago. In: Delasalle B, Galzin R, Salvat B (eds) 5th 388 International Coral Reef Congress, Tahiti. Papeete, Tahiti, p $269-322$

389 Diaz-Pulido G, McCook LJ, Dove S, Berkelmans R, Roff G, Kline DI, Weeks S, Evans RD, 390 Williamson DH, Hoegh-Guldberg O. 2009. Doom and boom on a resilient reef: climate change, algal overgrowth and coral recovery. PLoS One 4:e5239

Eakin CM, Morgan JA, Heron SF, Smith TB, Liu G, Alvarez-Filip L, Baca B, Bartels E, Bastidas C, Bouchon C, Brandt M, Bruckner AW, Bunkley-Williams L, Cameron A, Causey BD, Chiappone M, Christensen TRL, Crabbe MJC, Day O, la Guardia E de, Díaz-Pulido G, DiResta D, GilAgudelo DL, Gilliam DS, Ginsburg RN, Gore S, Guzmán HM, Hendee JC, Hernández-Delgado EA, Husain E, Jeffrey CFG, Jones RJ, Jordán-Dahlgren E, Kaufman LS, Kline DI, Kramer PA, Lang JC, Lirman D, Mallela J, Manfrino C, Maréchal J-P, Marks K, Mihaly J, Miller WJ, Mueller EM, Muller EM, Orozco Toro CA, Oxenford HA, Ponce-Taylor D, Quinn N, Ritchie KB, Rodríguez S, Ramírez AR, Romano S, Samhouri JF, Sánchez JA, Schmahl GP, Shank B V, Skirving WJ, Steiner SCC, Villamizar E, Walsh SM, Walter C, Weil E, Williams EH, Roberson KW, Yusuf Y. 2010. Caribbean corals in crisis: record thermal stress, bleaching, and mortality in 2005. PLoS One 5:e13969

Emslie M, Cheal A, Sweatman H, Delean S. 2008. Recovery from disturbance of coral and reef fish communities on the Great Barrier Reef, Australia. Marine Ecology Progress Series 371:177-190

Emslie MJ, Pratchett MS, Cheal AJ. 2011. Effects of different disturbance types on butterflyfish communities of Australia's Great Barrier Reef. Coral Reefs 30:461-471 
409 Feary D, Almany G, Jones G, McCormick M. 2007. Coral degradation and the structure of tropical reef 410 fish communities. Marine Ecology Progress Series 333:243-248

411 Froese R, Pauly D. 2014. FishBase. World Wide Web electronic publication.

$412 \quad$ www.fishbase.org (accessed 10 October 2014)

413 Gardner TA, Côté IM, Gill JA, Grant A, Watkinson AR. 2003. Long-term region-wide declines in $414 \quad$ Caribbean corals. Science 301:958-60

415 Garpe K, Yahya S, Lindahl U, Öhman M. 2006. Long-term effects of the 1998 coral bleaching event 416 on reef fish assemblages. Marine Ecology Progress Series 315:237-247

417 Glynn P, Enochs I, Afflerbach J, Brandtneris V, Serafy J (2014) Eastern Pacific reef fish responses to 418 coral recovery following El Niño disturbances. Marine Ecology Progress Series 495:233-247

419 Gilmour JP, Smith LD, Heyward AJ, Baird AH, Pratchett MS. 2013. Recovery of an isolated coral reef system following severe disturbance. Science 340:69-71

Graham NAJ, Nash KL. 2013. The importance of structural complexity in coral reef ecosystems. Coral Reefs 32:315-326

Graham NAJ, Wilson SK, Pratchett MS, Polunin NVC, Spalding MD. 2009. Coral mortality versus structural collapse as drivers of corallivorous butterflyfish decline. Biodiversity and Conservation $18: 3325-3336$

Graham NAJ, Wilson SK, Jennings S, Polunin NVC, Bijoux JP, Robinson J. 2006. Dynamic fragility of oceanic coral reef ecosystems. Proceedings of the National Academy of Sciences USA 103:8425-9

Graham NAJ, Wilson SK, Jennings S, Polunin NVC, Robinson J, Bijoux JP, Daw TM. 2007. Lag effects in the impacts of mass coral bleaching on coral reef fish, fisheries, and ecosystems. Conservation Biology 21:1291-300 
432 Halford A, Cheal AJ, Ryan D, Williams DM. 2004. Resilience to large-scale disturbance in coral and 433 fish assemblegaes on the great barrier reef. Ecology 85:1892-1905

434 Holbrook S, Schmitt R, Brooks A. 2008. Resistance and resilience of a coral reef fish community to $435 \quad$ changes in coral cover. Marine Ecology Progress Series 371:263-271

436 Hughes TP, Baird AH, Bellwood DR, Card M, Connolly SR, Folke C, Grosberg R, Hoegh-Guldberg 437 O, Jackson JBC, Kleypas J, Lough JM, Marshall P, Nyström M, Palumbi SR, Pandolfi JM, Rosen 438 B, Roughgarden J. 2003. Climate change, human impacts, and the resilience of coral reefs. $439 \quad$ Science 301:929-33

440 Jones GP, McCormick MI, Srinivasan M, Eagle JV. 2004. Coral decline threatens fish biodiversity in 441 marine reserves. Proceedings of the National Academy of Sciences USA 101:8251-8253

442 Leray M, Béraud M, Anker A, Chancerelle Y, Mills SC. 2012. Acanthaster planci outbreak: decline in 443 coral health, coral size structure modification and consequences for obligate decapod $444 \quad$ assemblages. PLoS One 7:e35456

445 Lison de Loma T, Osenberg CW, Shima JS, Chancerelle Y, Davies N, Brooks AJ, Galzin R. 2008. A 446 Framework for Assessing Impacts of Marine Protected Areas in Moorea (French Polynesia) $447 \quad$ Pacific Science 62:431-441

448 Mumby PJ, Chisholm J, Edwards AJ, Clark C, Roark E, Andrefouet S, Jaubert J. 2001. Unprecedented 449 bleaching-induced mortality in Porites spp. at Rangiroa Atoll, French Polynesia. Marine Biology $450 \quad 139: 183-189$

451 Ninio R, Meekan MG, Done T, Sweatman H. 2000. Temporal patterns in coral assemblages on the 452 Great Barrier Reef from local to large spatial scales. Marine Ecology Progress Series 194:65-74 
453 Pandolfi JM, Bradbury RH, Sala E, Hughes TP, Bjorndal KA, Cooke RG, McArdle D, McClenachan

454 L, Newman MJH, Paredes G, Warner RR, Jackson JBC. 2003. Global trajectories of the long-term 455 decline of coral reef ecosystems. Science 301:955-8

456 Pratchett M, Munday P, Wilson K, Jones GP, Mcclanahan TR. 2008. Effects of climate-induced coral 457 bleaching on coral reef fishes - ecological and economic consequences. Oceanography and 458 Marine Biology an Annual Review 46:251-296

459 Roff G, Bejarano S, Bozec Y-M, Nugues M, Steneck RS, Mumby PJ. 2014. Porites and the Phoenix 460 effect: unprecedented recovery after a mass coral bleaching event at Rangiroa Atoll, French $461 \quad$ Polynesia. Marine Biology 161:1385-1393

462 Salvat B, Aubanel A, Adjeroud M, Bouisset P, Calmet D, Chancerelle Y, Cochennec N, Davies N, 463 Fougerousse A, Galzin R, Lagouy E, Lo C, Monier C, Ponsonnet C, Remoissenet G, Schneider D, 464 Stein A, Tatarata M, Villiers L, Schutte V, Selig E, Bruno JF. 2010. Monitoring of French 465 Polynesia coral reefs and their recent development. Revue D'Ecologie-La Terre La Vie 63:145$466 \quad 177$

467 Sano M. 2000. Stability of reef fish assemblages: responses to coral recovery after catastrophic 468 predation by Acanthaster planci. Marine Ecology Progress Series 198:121-130

469 Sano M, Shimizu M, Nose Y. 1987. Long-term effects of destruction of hermatypic corals by 470 471

472 Schutte V, Selig E, Bruno J. 2010. Regional spatio-temporal trends in Caribbean coral reef benthic 473 communities. Marine Ecology Progress Series 402:115-122 
474 Swaetman H, Cheal AJ, Coleman G, Delean S, Fitzpatrick B, Miller I, Ninio R, Osborne K, Page C, 475 Thompson A. 2001. Long-term monitoring of the Great Barrier Reef n5. Australian Institute of $476 \quad$ Marine Science, Townsville, Australia

477 Terlizzi A, Benedetti-Cecchi L, Bevilacqua S, Fraschetti S, Guidetti P, Anderson M. 2005.

478 Multivariate and univariate asymmetrical analyses in environmental impact assessment: a case 479 study of Mediterranean subtidal sessile assemblages. Marine Ecology Progress Series 289:27-42 480 Wilkinson C 2008. Status of coral reefs of the world: 2008. Townsville, Australia 481 Wilson SK, Burgess SC, Cheal AJ, Emslie M, Fisher R, Miller I, Polunin NVC, Hugh P, Sweatman A 482 2008. Habitat utilization by coral reef fish : implications for specialists vs. generalists in a 483 changing environment. Journal of Animal Ecology 77:220-228

484 Wilson SK, Dolman AM, Cheal AJ, Emslie MJ, Pratchett MS, Sweatman HPA. 2008. Maintenance of 485 fish diversity on disturbed coral reefs. Coral Reefs 28:3-14

486 Wilson SK, Graham NAJ, Pratchett MS, Jones GP, Polunin NVC 2006. Multiple disturbances and the 487 global degradation of coral reefs: are reef fishes at risk or resilient? Global Change Biology $488 \quad 12: 2220-2234$ 


\section{Table $\mathbf{1}_{\text {(on next page) }}$}

Table 1. Reef fish taxa that contributed disproportionately to dissimilarity in fish community composition between 1981 and 2012 on coral reefs of the Mataiva lagoon

Table 1. Reef fish taxa that contributed disproportionately to dissimilarity in fish community composition between 1981 and 2012 on coral reefs of the Mataiva lagoon. Mean densities (\# per $250 \mathrm{~m}^{2} \pm 1 \mathrm{SD}$ ), consistency ratios, and individual and cumulative contributions (in \%) to differences between years are shown. Asterisks denote species considered to be reliant on live coral for shelter or food. The consistency ratio is calculated as a species' average dissimilarity contribution divided by the standard deviation of dissimilarity values. The species in grey has a consistency ratio $<1$, which indicates an uneven contribution to community dissimilarity across sites. The analysis was conducted on square-root-transformed data (see Methods) but untransformed densities are presented here 
2

3

4

5

6

7

8

9

10

11

12

13

14

15

16

17

18

19

20

21

22

23

24

25

26

27

28

29

30

31

32

33

34

35

36

37

\begin{tabular}{|c|c|c|c|c|c|}
\hline \multirow[t]{2}{*}{ Species } & \multicolumn{2}{|c|}{$\begin{array}{l}\text { Mean density } \\
\text { (SD) }\end{array}$} & \multirow[t]{2}{*}{$\begin{array}{l}\text { Consistency } \\
\text { ratio }\end{array}$} & \multirow{2}{*}{$\begin{array}{c}\text { Individual } \\
\text { contribution } \\
(\%)\end{array}$} & \multirow{2}{*}{$\begin{array}{c}\text { Cumulative } \\
\text { contribution } \\
(\%)\end{array}$} \\
\hline & 1981 & 2012 & & & \\
\hline Chlorurus sordidus & $\begin{array}{c}9.9 \\
(18.9)\end{array}$ & $\begin{array}{c}51.1 \\
(33.7)\end{array}$ & 1.62 & 10.64 & 10.6 \\
\hline Chromis viridis* & $\begin{array}{l}26.7 \\
(29.3)\end{array}$ & $\begin{array}{l}34.1 \\
(49.3)\end{array}$ & 1.37 & 8.46 & 19.10 \\
\hline Dascyllus aruanus* & $\begin{array}{c}7.2 \\
(11.5)\end{array}$ & $\begin{array}{c}23.2 \\
(29.5)\end{array}$ & 1.20 & 6.08 & 25.17 \\
\hline Acanthurus triostegus & $\begin{array}{l}5.0 \\
(6.9)\end{array}$ & $\begin{array}{c}2.8 \\
(10.4)\end{array}$ & 1.30 & 4.11 & 29.28 \\
\hline $\begin{array}{l}\text { Thalassoma hardwicke } \\
\text { (2.0) }\end{array}$ & $\begin{array}{l}1.2 \\
(6.1)\end{array}$ & 6.9 & 1.49 & 3.77 & 33.05 \\
\hline Stegastes nigricans* & $\begin{array}{c}1.5 \\
(4.2)\end{array}$ & $\begin{array}{c}10.7 \\
(21.4)\end{array}$ & 0.64 & 3.51 & 36.56 \\
\hline Scarus spp & $\begin{array}{l}8.6 \\
(14.9)\end{array}$ & $\begin{array}{l}5.5 \\
(5.0)\end{array}$ & 1.25 & 3.05 & 39.61 \\
\hline Chaetodon lunulatus* & $\begin{array}{l}2.3 \\
(4.8)\end{array}$ & $\begin{array}{l}4.3 \\
(4.4)\end{array}$ & 1.45 & 3.04 & 42.66 \\
\hline Halichoeres trimaculatus & $\begin{array}{c}0 \\
(0)\end{array}$ & $\begin{array}{l}3.9 \\
(5.1)\end{array}$ & 1.24 & 2.87 & 45.53 \\
\hline Amblygobius phalaena & $\begin{array}{l}10.2 \\
(9.0)\end{array}$ & $\begin{array}{c}8.7 \\
(5.6)\end{array}$ & 1.26 & 2.42 & 47.94 \\
\hline
\end{tabular}




\section{1}

The reticulated lagoon of Mataiva

Fig. 1. The reticulated lagoon of Mataiva, where coral cover and fish diversity and abundance were recorded in 1981 and 2012 (Photo: Suzanne C. Mills)

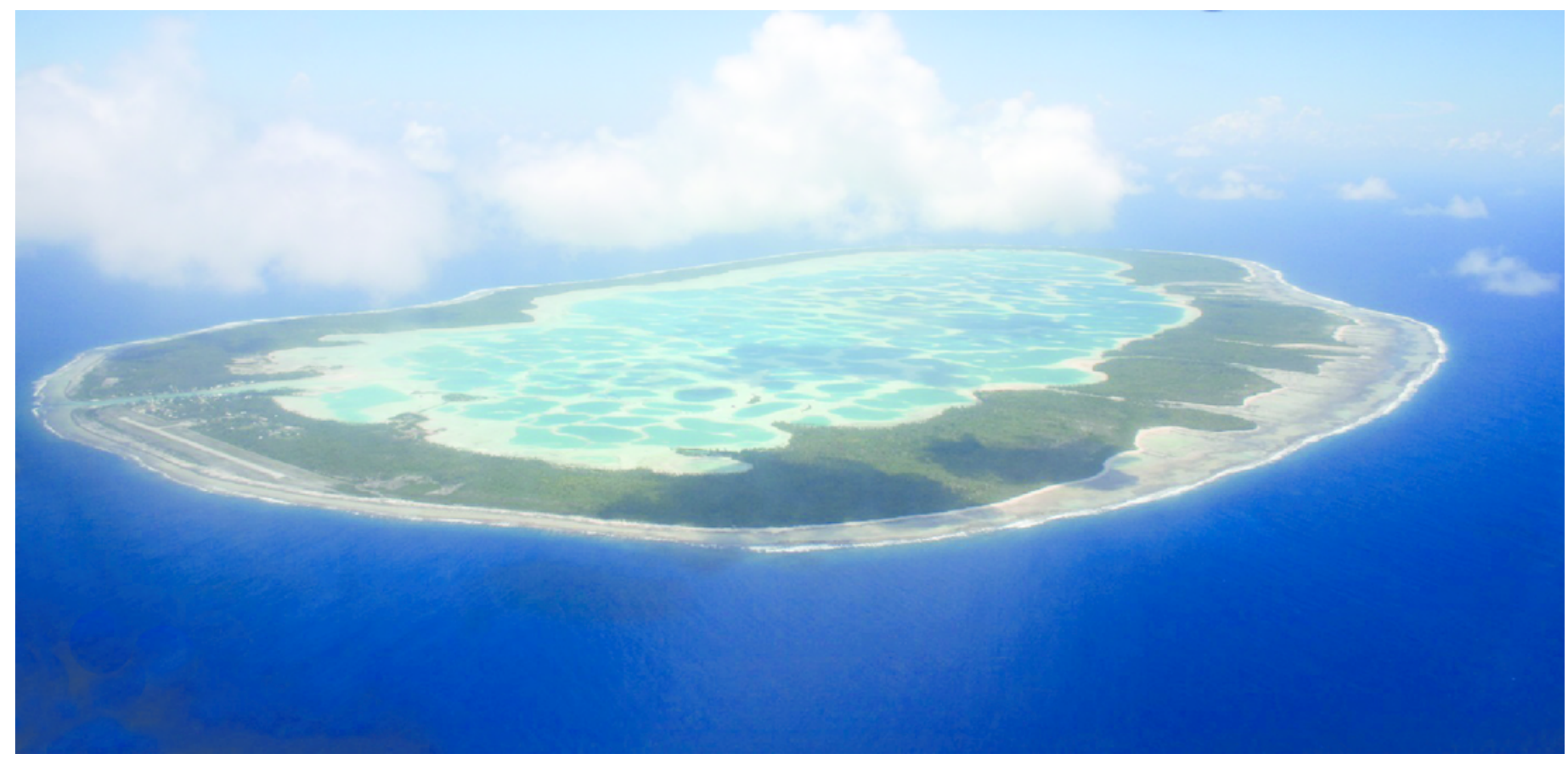


2

Changes in live coral cover, fish species richness (\# fish species per $250 \mathrm{~m}^{2}$ ), and fish density (\# fish per $250 \mathrm{~m}^{2}$ ) on coral reefs of the Mataiva lagoon between 1981 and 2012

Fig. 2 - Changes in (a) live coral cover, (b) fish species richness (\# fish species per $250 \mathrm{~m}^{2}$ ), and (c) fish density (\# fish per $250 \mathrm{~m}^{2}$ ) on coral reefs of the Mataiva lagoon between 1981 and 2012. Each line represents a site, and the trajectory for each site is colour-coded to match the initial category of coral cover reported for 1981 in Bell \& Galzin(1984): 0\%, black; $<2 \%$, blue; $2-<5 \%$, green; $5-10 \%$, orange; $>10 \%$, red. Some points with similar values are offset for clarity
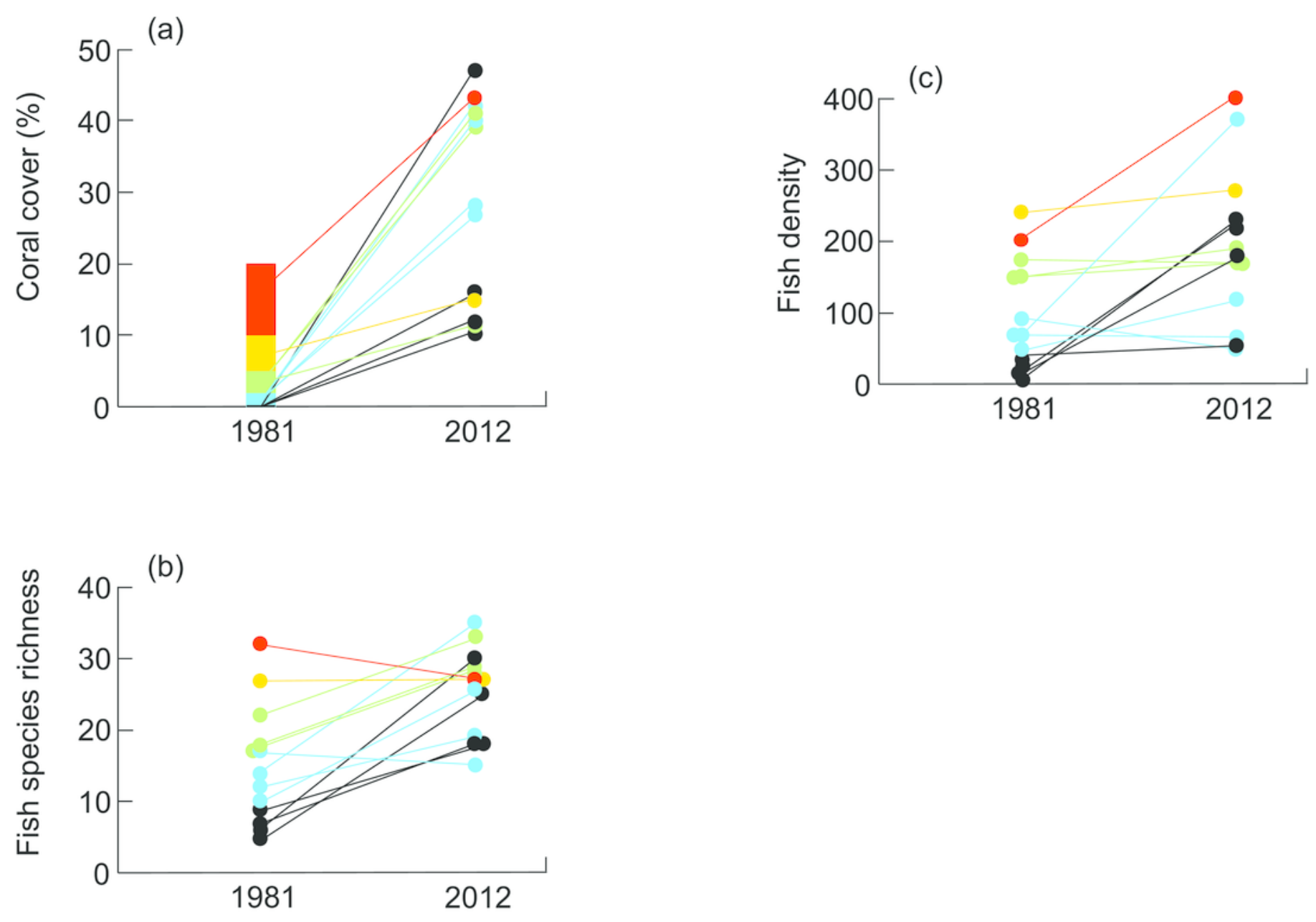
3

Multidimensional scaling plot of reef fish community composition from the Mataiva Atoll lagoon, French Polynesia

Fig. 3 - Multidimensional scaling plot of reef fish community composition from the Mataiva Atoll lagoon, French Polynesia. Each point represents the reef fish assemblage of a pool within the lagoon in 1981 (red points) and 2012 (blue points). The low stress value (0.08) suggests that the three-dimensional depiction shown reflects well differences among communities

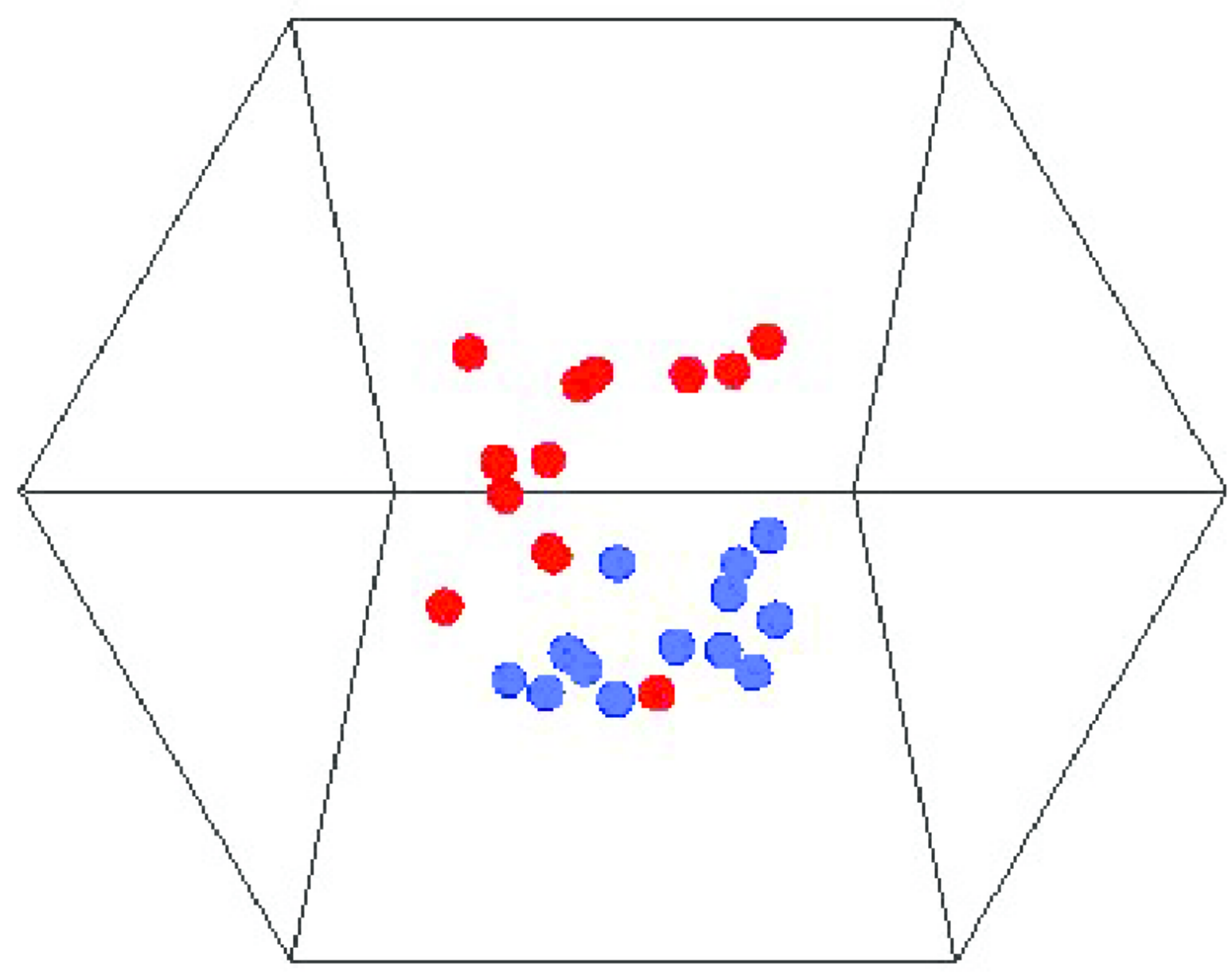




\section{4}

Relationships between live coral cover and (a) reef fish species richness and (b) density

Fig. 4. Relationships between live coral cover and (a) reef fish species richness (\# fish species per $250 \mathrm{~m}^{2}$ ) and (b) density (\# fish per $250 \mathrm{~m}^{2}$ ) in 1981 (red points and regression lines) and in 2012 (blue points and regression lines). Superimposed points are offset slightly for clarity. Regression equations (a) 1981: $Y=0.53 * X+11.9 ; 2012: Y=-0.006 * X+25.4$; (b) 1981: $Y=11.1 * X+53.1 ; 2012: Y=-0.12 * X+196.4$ 

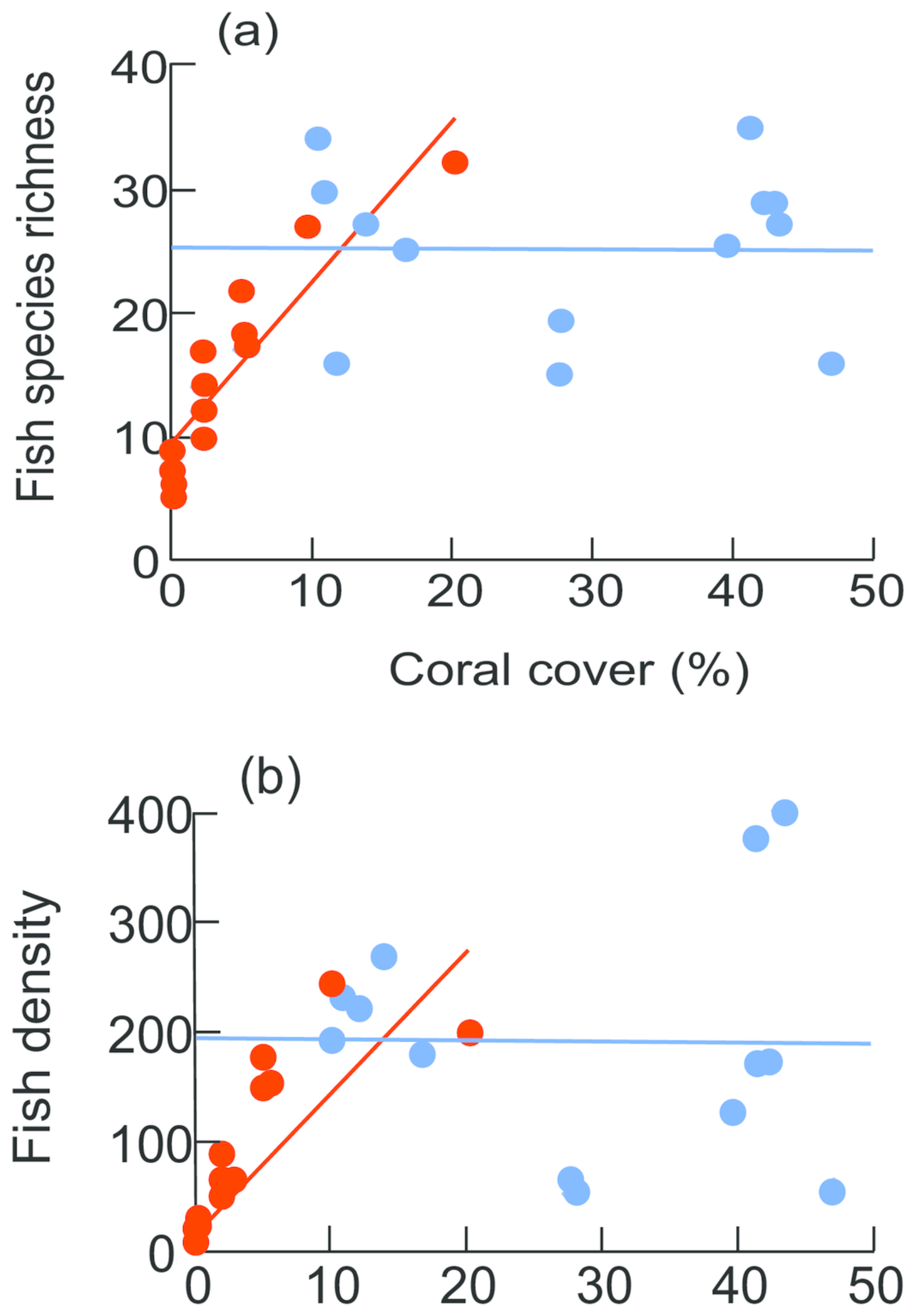